\title{
Pico della Mirandola on the Dignity of Man and Some Contemporary Echoes of His Philosophy
}

\section{Marko Uršič*}

Pico della Mirandola (1463-1494), one of the finest Renaissance minds, endeavored in his short life to establish a universal synthesis of all contemporary philosophical and religious doctrines. Not only to unite Platonic and Aristotelian philosophies, as many had already tried before him, but also to reconcile three main monotheistic religions among themselves, as well as with various Hermetic, Kabbalistic, Orphic, Zoroastrian, and other spiritual traditions. ${ }^{1}$ As a rich man, Pico proposed to pope Innocent VIII in 1486 to organize on Pico's own expenses a great public disputation, or "council" in Rome. He would reveal a new theological and philosophical system for the reconciliation of all principal doctrines and beliefs. For this purpose, Pico prepared 900 theses, Conclusiones in Latin, and the oration De dignitate hominis (On the Dignity of Man), which was intended as the introductory speech to open the council. However, after almost a year-long reviewing of Pico's theses, Innocent VIII, with his cardinals, rejected Pico's project and condemned his Conclusiones as heretical.

The Oration on the Dignity of Man is a vibrant and brilliantly written treatise on various philosophical and theological topics. This paper's scope is Pico's principal statement that the critical quality, establishing the highest value of man compared with other created

* Faculty of Arts, University of Ljubljana, Aškerčeva 2, 1000 Ljubljana, Slovenia; marko.ursic@guest.arnes.si.

1 The paper was presented at the conference on "European Humanism and Its Challenges," organized by the University of Ljubljana, the University of Warsaw, and Central European University on September 8-9, 2017 as part of the Vilenica International literary festival. 
beings - from the inanimate nature to angels - is the human free will. Free will is our freedom to shape the very form of our being by ourselves. However, this presents a paradox that is the main topic of this paper. Let us go step-by-step, beginning with Pico's famous introductory words to his oratio:

Most esteemed Fathers, I have read in the ancient writings of the Arabians that Abdala the Saracen on being asked what, on this stage, so to say, of the world, seemed to him most evocative of wonder, replied that there was nothing to be seen more marvellous than man. And that celebrated exclamation of Hermes Trismegistus, "What a great miracle is man, Asclepius" confirms this opinion. ${ }^{2}$

This is a very Renaissance statement, emphasized by the famous words of Hermes Trismegistus, by his Asclepius in the Corpus Hermeticum, highly regarded by the scholars of the time. It is also characteristic that Pico mentions a Muslim sage in the very first sentence of his speech. Subsequently, Pico exclaims: "Oh unsurpassed generosity of God the Father, oh wondrous and unsurpassable felicity of man, to whom it is granted to have what he chooses, to be what he wills to be!"3 However, in this generous God's gift to man lies a paradox. It may be expressed in two mutually related formulations. 1) God defined man (or man's essence) by not defining him. 2) Man, in his freedom of will, cannot refuse this generous gift of God, even if it turns to be a Danaian gift someday, namely in case when God disappears from the stage. Pico proceeds, in God's name:

We have given you, O Adam, no visage proper to yourself, nor endowment properly your own, in order that whatever place, whatever form, whatever gifts you may, with premeditation, select, these same you may have and possess through your own judgment and decision. The nature of all other creatures is defined and restricted within laws which We have laid down; you, by contrast, impeded by no such restrictions, may, by your own free will, to whose custody We have assigned you, trace for yourself the lineaments of your own nature. ${ }^{4}$

2 All quotes from Pico's Oration of the Dignity of Man are from the English translation by A. Robert Caponigri, 1996.

3 Ibid.

4 Ibid. 
Well, it sounds indeed very generous and wise from God's side, but on the other hand, as we know from the Holy Bible, Adam's and Eve's "free will" implied their Fall from the garden of Eden, the earthly paradise (where, as one may guess, all the other animals remained). In Renaissance thought, the free will of man (and woman, of course) came to be closely connected with the human soul's central metaphysical position, as already stated by Marsilio Ficino and developed some years later by his young friend Pico. As the latter wrote:

I have placed you at the very centre of the world, so that from that vantage point you may with greater ease glance round about you on all that the world contains. We have made you a creature neither of heaven nor of earth, neither mortal nor immortal, in order that you may, as the free and proud shaper of your own being, fashion yourself in the form you may prefer. It will be in your power to descend to the lower, brutish forms of life; you will be able, through your own decision, to rise again to the superior orders whose life is divine. ${ }^{5}$

Following Marsilio Ficino, the human soul is the copula mundi, "the bond of the world." Otherwise said, Man's position in the universe is central - and that is, as we know, the prevailing view of the Renaissance period as a whole. However, this does not mean that Man is the highest creature in the universe, since the angels are still above him and, of course, God above them all. Considering Man's “central position" in the Renaissance, one has to stress and keep in mind that it is not yet such a central (and consequently also lonely) position. This will develop in the Modern, post-Renaissance age - Man as the founding Cartesian cogito or, later, as the principal ontological subject of the world. The modern subjectification of the human intellect will begin, in a strict sense, in the 17 th century, in the "Age of Reason," lasting up to the present, with several vital transformations. Again, there is a significant difference between the Renaissance Man, philosophically presented and discussed in Ficino's or Pico's treatises, and the modern concept of Man as Subject. The latter "constitutes" the world (cf. Kant's transcendental philosophy) and finally establishes and judges all values by himself (e.g., in Nietzsche).

The Renaissance period, especially the Neoplatonism in Florence in the second part of the quattrocento, reveals - centuries later, in 
the time of decline or at least of a profound crisis of the Modern Age - a paramount and precious harmony between opposites. This can be understood, following another philosopher of the 15th century, Nicolas of Cusa, as the universal coincidentia oppositorum. In the present context, this coincidentia, or universal harmony, means the equilibrium between Man and God, between God's creation of Man and Man's free will. There is no paradox here for Pico, while from Modern or Post-Modern points of view, this coincidentia seems paradoxical, a problem that has to be solved somehow, whether in God's or Man's favor.

Before saying more about the modern dilemma, either God or Man, I would like to draw attention to the last part of Pico's passage quoted above. Pico knows that the individual in his (or her) freedom is always on the brink, on the edge: one can rise to angels, but also fall "to the lower, brutish forms of life." Unfortunately, this falling of individuals and humanity in general has been happening all the time. So they always have to make an effort, strive to live and think in better and higher spheres of being.

By reading Pico's oration, another compelling and vital question might be raised. To what extent can humans - as living and embodied souls - ascend to the higher spheres of being? Pico believes that we can reach angelic life, even more, that "all are Gods," that the deification of every man or a woman is possible if his or her soul is bright and good enough. He knows that this idea has been considered heretical (as Hermetic, Gnostic, or worse). So he needs to support it with a quote from the Bible: "... and that the saying of Asaph the Prophet, You are all Gods and sons of the Most High [Psalm 82.6], might rather be true..."7 In his fervent vigor to rise spiritually as high as it is possible for Man, Pico believes that humans might be equal to angels, or placed even higher:

Let us [...] hasten to that court beyond the world, closest to the most exalted Godhead. There, as the sacred mysteries tell us, the Seraphim, Cherubim, and Thrones occupy the first places; but, unable to yield to them, and impatient of any second place, let us emulate their dignity and glory. And, if we will it, we shall be inferior to them in nothing. ${ }^{8}$ 
Even more, we might rise to the highest throne of God and become "one spirit" with Him, our Father in Heaven:

And if, dissatisfied with the lot of all creatures, he [Man] should recollect himself into the centre of his own unity, he will there become one spirit with God, in the solitary darkness of the Father, Who is set above all things, himself transcend all creatures. ${ }^{9}$

As already stated, such deification of the human soul is an old religious idea and a mystical vision. It was present and was expressed in several esoteric spiritual doctrines (mostly heretical from the orthodox theological point of view): from Gnosticism and Hermeticism to Sufism, and in many branches of Eastern spirituality. Understood in its more profound sense - and not as an idea that Man can or even should replace God by becoming the Master of the world - this idea of the deification of Man might be valuable. It can be revelatory also today, in our "post-time." It brings the presence of God closer and deeper into the human soul and spirit.

It seems that Pico della Mirandola, with his philosophy of human freedom, is a distant predecessor of Jean-Paul Sartre, the prominent defender of human freedom among the philosophers of the 20 th century. In a certain sense, this might be true, but there are essential differences between them, not only due to their historical distance, which is relative when comparing great philosophers. Sartre is a radical atheist, and consequently, his existentialism is very different from Pico's Renaissance doctrine of free will. In his famous essay "Existentialism is a Humanism" (1946), Sartre explains his philosophical axiom in the following way: "What do we mean by saying that existence precedes essence? We mean that man first of all exists, encounters himself, surges up in the world - and defines himself afterwards." ${ }^{\prime \circ}$ - One may assume that Pico could agree with Sartre's "self-definition" of man. However, Pico would surely disagree with Sartre's underlying argument for human freedom, as the latter states

Ibid.

10 English translation quoted from the translation by Philip Mairet, in Existentialism and Humanism, 1956. 
that "there is no human nature because there is no God to have a conception of it. Man simply is." "11

An almost logical sequel of Sartre's atheism, combined with his philosophical belief of free will, is our human anguish. We are alone in all our decisions since God is no more on the stage, neither behind the stage. Pico, on the contrary, was far from existential Angst as a sequel to human liberty. Much later, "Abraham's anguish" became one of the principal ethical problems in the modern philosophy of religion (cf. Kierkegaard, Sartre, Levinas). In the Renaissance, it did not yet exist as a relevant philosophical problem. One may guess that Pico would be surprised upon hearing Sartre's existentialist dilemma, "If a voice speaks to me, it is still I myself who must decide whether the voice is or is not that of an angel." ${ }^{.12}$ His probable answer would be in accord with the Renaissance spirit, with the pre-Cartesian and pre-Humean confidence in the human senses: "Of course it is the voice of an angel, provided that I hear his divine words ..." - And if one continues with Sartre's existentialist sequence of thoughts, they lead to the (in)famous position of Dostoevsky's Great Inquisitor:

Dostoevsky once wrote: "If God did not exist, everything would be permitted"; and that, for existentialism, is the starting point. Everything is indeed permitted if God does not exist, and man is in consequence forlorn, for he cannot find anything to depend upon either within or outside himself. [...] In other words, there is no determinism - man is free, man is freedom. [...] We are left alone, without excuse. That is what I mean when I say that man is condemned to be free. [... Man] is responsible for everything he does. [... Every man] is thereby at the same time a legislator deciding for the whole of mankind ... ${ }^{13}$

Considering this Sartre's passage, one might firstly deny the necessity of Dostoevsky's (more precisely, Ivan Karamazov's) statement that "If God did not exist, everything would be permitted." Namely by arguing from the point of the ethical Golden Rule and the Kantian autonomous categorical imperative, which is also valid for atheists. However, this would be a topic for another, long, and complicated discussion. In the context of this paper, I would like to point out - without any explicit theological commitments - that it is hard, 
maybe even impossible, to overcome Sartre's existential anguish without any transcendence. Even if one accepts the Kantian autonomy of ethics, die Angst persists when everything, every decision and event in the world, is devoid of any transcendent meaning. To put it otherwise, if all immanence is entirely devoid of transcendence, all the world is just flat, only a surface without any depth or height. True, Sartre also spoke about transcendence, but in a different, existentialist sense. The principal feature of his conception of transcendence is the "self-surpassing" of man, namely, every human being can live their autonomous and authentic life as his free project:

But there is another sense of the word [humanism], of which the fun-
damental meaning is this: Man is all the time outside of himself: it is
in projecting and losing himself beyond himself that he makes man
to exist; and, on the other hand, it is by pursuing transcendent aims
that he himself is able to exist. [...] Man is thus self-surpassing [...]
He is himself the heart and center of his transcendence. [...] There is
no other universe except the human universe, the universe of human
subjectivity. [...] - it is this that we call existential humanism. ${ }^{14}$

One may remark again that Pico would probably agree with these statements, except the one where Sartre says: "There is no other universe except the human universe, the universe of human subjectivity." As already stated, the Renaissance was not subjective in the Modern sense of the world, although the Renaissance Man was supposed to be the center of the world, and the human soul was considered as the copula mundi.

Nowadays, one can find several post- or post-post-modern versions of radical atheism in the philosophical or broadly cultural attitudes of many thinkers: in Richard Dawkins's God Delusion (2006), in the works of some post-structuralist philosophers, and elsewhere. In our context, I have chosen the French writer Pascal Quignard for a short discussion of his ideas about religion, at least implicitly connected with Pico's concept of human dignity and free will. In his book of essays, The Silent Crossing (La barque silencieuse, 2009), Quignard proposed the following general definition of atheism and an atheist person:

I term "atheist" the person who lives without gods, whose soul is without faith, whose consciousness is exempt from fear, whose mor- 
als are not based on rites, whose thought is exempt from any reference to god, devil, demon, hallucination, love or obsession, whose death is accessible to the idea of suicide, whose post-death is nothingness. ${ }^{15}$

However, Quignard concedes in a rather Voltairean manner that, "as regards what drives the spirit, I think atheism is impossible, since it is not possible wholly to wrest a humanity which speaks from the verbal hallucination and abstract ideas that gradually emanate from words ..." ${ }^{\prime 6}$ Although in principle such a "wrest" would be welcome from his point of view, since reality is always better than "hallucination." (One may add here the old and never-solved question: What is reality, and what is hallucination?) Quignard comments realistically: "Lucidity may be regarded as a higher value than illusion. But however this may be, and however little we may like it, the desire to believe is reborn like sleep or thirst, or like the attachment of love or the desire to be happy."17 If it is indeed, why should one deny it and flee away from it?

One may state that the common denomination of diverse atheist and liberal criticisms of religion is a presupposed belief that the religious faith, mind, and rituals are essentially dependent on human social and political life. To put it otherwise, that religions are sociological (and psychological) phenomena, not primarily the human attitudes and answers to the unknown, enigmatic and mysterious cosmic or metaphysical reality itself. This presumed mundane origin of religion is also inherent in the following passage from Quignard: "To live without god is an extreme human possibility. It is not actually the impious individual who is condemned in atheism but the traitor of the group. This is why the chronicle of atheism is a history of continuous, endless persecution. ${ }^{.18}$ Unfortunately, while this statement is itself not wrong, the problem with such a reductive understanding of religion is that it is only partly true. It does not express the whole truth of religious faith, not even its main $\tau \dot{\varepsilon} \lambda$ oc, its important role in our search for the meaning of life. Hélas, one could not argue rationally against Quignard when he states that:

Moses, Jesus, Mohammed seemed to them [atheists] to be tyrannical masters laying claim to the totality of the social field. The dogmas of three prophets had contrived a control over people's souls, which 
they hemmed in with prescriptions and terrors [... and] century after century, took millions and tens of millions of bodies and sacrificed them in crusades or martyrdom. ${ }^{19}$

Unfortunately, this statement contains more than just a grain of truth. As revealed in their sacred scriptures, monotheistic religions prescribe numerous commandments, and many of them serve principally for the formation of one or other confessional social identity. One knows from history and from our contemporary world that religious identities, when considered as social and political denominations, are too often motives and even causes for conflicts, wars, terrorism. Nevertheless, nowadays, the right question concerning religion should be the following: How can one save and preserve religion as a valuable, maybe the utmost precious spiritual attitude of man towards the unknown, transcendent God, without being in perpetual danger that religious beliefs may lead people into tragic conflicts?

There were many different answers to this crucial question in the long history of humankind and all variety of religious beliefs. Nowadays, we have to, first of all, accept the autonomy of human ethics (and politics) concerning various and sometimes also conflicting religious commandments. The fundamental ethical maxim for believers and atheists remains the Golden Rule: One should treat others as one would like others to treat oneself (there are several, but almost equivalent variants). In this sense, Sartre was right. We are alone in the world and entirely responsible for our decisions, what we do and what we do not do. We are free in our decisions and acts; therefore, we have to be fully responsible for them.

From this point on, there are (at least) three ways to avoid religious intolerance and, at the same time, preserve the precious jewel of religions.

1. The most prominent answer in the Western world is the central message of Jesus Christ: Love is the only commandment. Unfortunately, despite this spiritual core of the New Testament, this "religion of love" has lead in the praxis of the Church (in fact, of several Christian churches) to tragic conflicts, to the persecution of heretics, atheists, and those who believed otherwise as prescribed by the Church. That is why believers and atheists have to return to Christ's first message of love - since all other religious doctrines are eventually not so important. 
2. Another way to avoid intolerance, generated from different religions and their role in social and political life, is the mystical way. Mystics, such as Meister Eckhart in Christianity or Sufis in Islam or arhats in Buddhism, have always been solitary souls, detached from the world in their cultural surroundings. Their thoughts, visions, and love have always been directed only towards God as the Spirit, the Saviour, the highest Light.

3. The third possible non-invasive religious way is pantheism in its several historical variants, from pre-Socratics to Spinoza, and even to Einstein's cosmic religiosity. Is it really true that pantheism is not compatible with theism - with some kind of belief in a personal God, the Father of Heaven? The history of Western culture knows intense endeavors for the reconciliation between the two "faces" of the same God, being both cosmic and personal. Philosophers were seeking the highest truth in this twofold, and at the same time unique, way: Plotinus, Nicholas of Cusa, Bruno, Schelling, Whitehead, Wittgenstein. According to Jan Assmann, this henotheism differs from the main three historical ("biblical") monotheisms in the following principal point: monotheism excludes all other gods, while henotheism includes them - together with and within the belief in

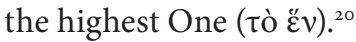

At the end of this paper, I am returning to Pico della Mirandola (who remained a Catholic). All three of the abovementioned non-invasive ways of religious belief enable and even substantially ground human free will. Genuine and real freedom consists not only of the freedom from something but also - and that is even more important, particularly nowadays - of the freedom for something good and beautiful. One needs the highest value that gives meaning, sense to life and the world. For me, personally, the third of the mentioned options or possible ways of "pure" religious and spiritual faith - namely some kind of pantheism that is compatible with "inclusive" theism - is within the reach of my mind and belief, at least in this period of my life. The other two ways, (1) that Jesus is the "highest Angel of Love" (if one may say so), and (2) "the mystical way" of great solitary souls, 
are present in my mind just as high ideals, much harder to reach by experience. Excepting some enlightened souls, we experience mystical contacts with transcendence rarely, if at all. However, one has to remain open for the Highest. I think that there is no real humanism without transcendence. ${ }^{21}$

Instead of a conclusion, I want to finish with these beautiful verses of Walt Whitman, quoted from the "Song of Myself," from Leaves of Grass:

Why should I wish to see God better than this day?

I see something of God each hour of the twenty-four, and each moment then,

In the faces of men and women I see God, and in my own face in the glass, I find letters from God dropt in the street, and every one is sign'd by God's name, And I leave them where they are, for I know that wheresoeer I go, Others will punctually come for ever and ever. ${ }^{22}$

21 Even in the pantheistic way(s), there is a kind of transcendence, which we may call the "transcendence-in-immanence," or figuratively, "the depth (or height) behind the surface," or the Light behind the "shadows of the world" (see also my Shadows of Being, 2018).

22 Whitman, Leaves of Grass and Selected Prose, 77-78. 


\section{BIBLIOGRAPHY}

Allen, Michael J. B., trans. Marsilio Ficino: Theologia Platonica / Platonic Theology. The I Tatti Renaissance Library. Cambridge, MA: Harvard University Press, 2001.

Assmann, Jan. Monotheismus und Kosmotheismus. Heidelberg: Universitätsverlag C. Winter, 1993.

Caponigri, A. Robert, trans. Giovanni Pico della Mirandola: Oration of the Dignity of Man. Washington, DC: Regnery Publishing, 1996.

Quignard, Pascal. The Silent Crossing. English translation of La barque silencieuse, 2009, by Chris Turner. London: Seagull Books, 2013.

Sartre, Jean-Paul. Existentialism and Humanism. English translation by Philip Mairet. London: Methuen, 1948.

Senegačnik, Brane, trans. Giovanni Pico della Mirandola: O človekovem dostojanstvu. Tretji dan. Ljubljana: Družina, 1997.

Uršič, Marko. "The Gaze of the Soul and of the Angel in the Renaissance Philosophy of Marsilio Ficino.” Ars \& Humanitas 9.1 (2015): 58-73.

- Shadows of Being: Four Philosophical Essays. Newcastle upon Tyne: Cambridge Scholars Publishing, 2018.

Whitman, Walt. Leaves of Grass and Selected Prose. London: Everyman, 1997. 


\section{ABSTRACT}

The Oration on the Dignity of Man makes a claim, characteristic for the Renaissance, that the dignity of man, the real "excellency of human nature," is not present in any specific human quality or ability. Neither is it present in the role of the human soul as the "tie of the world" (copula mundi), as Marsilio Ficino has taught. Even higher than this eminent human role in the world is the freedom of man to choose his role and task himself. At the same time, Pico believes that Man was created as the image of God, in the sense that no man is determined in advance: human free will reflects God's free will in creation. From the point of view of the mainstream modern dualism, this is a paradox, even a contradiction. This paper argues the opposite: that the human free will is even nowadays, not less than in the Renaissance period, compatible with the belief in God. However, this is only the case if God (being transcendent or immanent to the world) does not command anything, if God does not demand anything - except love. Violence and killing are eo ipso prohibited, especially in the name of faith. Therefore, freedom and faith are perfectly compatible. Even more, modern humans are fatally unfree either in the secular "radicalization" of faith or in the atheistic secularization of the world. Unfree due to their existence (Dasein), enslaved by the Angst of "mere nothing."

\section{KEYWORDS}

Pico della Mirandola, the Renaissance man, free will, Jean-Paul Sartre, Pascal Quignard 


\section{IZVLEČEK}

Pico della Mirandola o človekovem dostojanstvu

in nekaj sodobnih odmevov njegove filozofije

Pico della Mirandola je v govoru O človekovem dostojanstvu razvil za renesanso značilno misel, da človekovo dostojanstvo, tista prava »odličnost človeške narave«, ni v določeni človeški lastnosti ali sposobnosti, niti v tem, da je človeška duša "sponka sveta", kot je učil Marsilio Ficino, kajti še višja od te vzvišene človekove vloge $v$ stvarstvu je človekova svoboda, da si svojo vlogo in nalogo izbere sam. Obenem pa je Pico prepričan, da je človek ustvarjen po božji podobi, namreč ravno s tem, da ni vnaprej določen: človekova svobodna volja zrcali božjo svobodo pri stvarjenju. S stališča novoveškega dualizma je to paradoks, če ne že kar protislovje. V tem članku pa želim povedati, da je človeška svoboda tudi dandanes, nič manj kot $\mathrm{v}$ obdobju renesanse, združljiva $\mathrm{z}$ vero $\mathrm{v}$ Boga - vendar le tedaj, če Bog (bodisi transcendenten ali imanenten svetu) človeku ničesar ne zapoveduje, če v svetih spisih od človeka ničesar ne zahteva, niti ne pričakuje - ničesar razen ljubezni. S tem eo ipso prepoveduje nasilje in ubijanje, še posebej v imenu vere. Svoboda in vera sta povsem združljivi, še več, sodobni človek je usodno nesvoboden tako v posvetni »radikalizaciji« vere kakor tudi v ateistični sekularizaciji sveta, nesvoboden v temelju svoje tu-biti, zasužnjen s tesnobo »zgolj niča«.

\section{KLJUČNE BESEDE}

Pico della Mirandola, renesančni človek, svobodna volja, Jean-Paul Sartre, Pascal Quignard 